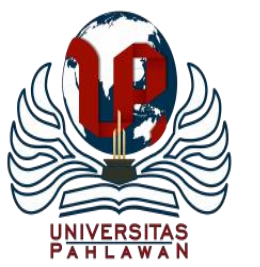

Jurnal Basicedu Volume 4 Nomor 2 April 2020 Hal. 460-466

JURNAL BASICEDU

Research \& Learning in Elementary Education

https://jbasic.org/index.php/basicedu

\title{
KONTRIBUSI IKLIM SEKOLAH DAN KEPEMIMPINAN KEPALA SEKOLAH TERHADAP KINERJA GURU SEKOLAH DASAR
}

\author{
Ideswal $^{1}$, Yahya $^{2}$, Hanif Alkadri ${ }^{3}$ \\ Universitas Negeri Padang, Sumatera Barat, Indonesia ${ }^{1,2,3}$, \\ E-mail : : Ideswal27@gmail.com, yahya@ fbs.unp.ac.id, hanifalkadri@ fip.unp.ac.id,
}

\begin{abstract}
Abstrak
Tujuan penelitian ini untuk melihat kontribusi iklim sekolah dan kepemimpinan kepala sekolah terhadap kinerja guru SDN di kota Payakumbuh. Jenis penelitian adalah penelitian kuantitatif dengan korelasi. Populasinya adalah guru-guru SDN di kota Payakumbuh sebanyak 229 guru. Data penelitian dikumpulkan melalui melakukan pengamatan terhadap prilaku kepala sekolah terhadap guru. Berdasarkan Hasil penelitian yang diperoleh menunjukkan bahwa Terdapat kontribusi antara iklim sekolah dengan kinerja guru di SDN di kota Payakumbuh sebesar 9,0\% dan Terdapat kontribusi antara kepemimpinan kepala sekolah dengan kinerja guru SDN di kota Payakumbuh sebesar 8,6\%. Dapat disimpulkan bahwa terlihat kontribusi iklim sekolah dan kepemimpinan kepala sekolah terhadap kinerja guru SDN di kota Payakumbuh.
\end{abstract}

Kata Kunci : Iklim Sekolah, Kepemimpinan Kepala Sekolah, Kinerja Guru.

\begin{abstract}
The purpose of this study was to look at the contribution of the school climate and school principal leadership to the performance of SDN teachers in the city of Payakumbuh. This type of research is quantitative research with correlation. The population is 229 elementary school teachers in the city of Payakumbuh. Research data were collected through observing the behavior of principals towards teachers. Based on the research results obtained indicate that there is a contribution between the school climate and the performance of teachers in SDN in Payakumbuh by $9.0 \%$ and There is a contribution between the leadership of the principal and the performance of SDN teachers in Payakumbuh by $8.6 \%$. It can be concluded that the contribution of the school climate and leadership of the school to the performance of SDN teachers in Payakumbuh is seen.

Keywords : School Climate, Principal Leadership, Teacher Performance
\end{abstract}

@Jurnal Basicedu 2020

$\triangle$ Corresponding author:

Address : Air Tawar Padang

Email : Ideswal27@gmail.com

Phone : 089531307164

ISSN 2580-3735 (Media Cetak)

ISSN 2580-1147 (Media Online) 
461 Kontribusi iklim sekolah dan kepemimpinan kepala sekolah terhadap kinerja guru sekolah dasarIdeswal, Yahya, hanif Alkadri, Ahmad Zikri

\section{PENDAHULUAN}

Pada era globalisasi saat ini, tantangan yang sedang dihadapi bangsa Indonesia adalah tuntutan akan kualitas sumber daya manusia yang lebih kompetitif, agar bisa bersaing dengan negaranegara lain (Muhson, 2010). Hal tersebut dapat diwujudkan dengan peningkatan sumber daya manusia dalam bidang pendidikan, mengingat bahwa pendidikan merupakan faktor utama dalam pembentukan pribadi manusia. Dimana melalui pendidikan maka seseorang akan menjadi pribadi yang kaya akan pengetahuan, sehingga mampu bersaing dengan bangsa lain (Suwardana, 2018).

Dalam upaya meningkatkan pendidikan bagi warga pemerintah Indonesia membentuk berbagai program, menyediakan fasilitas pendukung serta mebuat peraturan-peraturan terkait pendidikan (Fadhli, 2017). Salah satunya melalui pemberlakuan Undang-Undang No. 14 tahun 2005 tentang guru dan dosen yang juga dituangkan dalam Pembukaan Undang-Undang Dasar Negara Republik Indonesia Tahun 1945 yang menyatakan bahwa tujuan pendidikan nasional adalah untuk melindungi segenap bangsa dan seluruh tumpah darah Indonesia dan untuk memajukan kesejahteraan umum, mencerdaskan kehidupan bangsa, dan ikut melaksanakan ketertiban dunia berdasarkan kemerdekaan, perdamaian abadi, dan keadilan sosial (Republik Indonesia, 2005). Untuk mewujudkan tujuan nasional tersebut, pendidikan merupakan faktor yang sangat menentukan.

Selanjutnya, Pasal 31 Undang-Undang Dasar Negara Republik Indonesia Tahun 1945 mengamanatkan bahwa setiap warga negara berhak mendapat pendidikan (Rakhmawati et al., 2016)(Permendikbud, 2013). Berdasarkan hal tersebut, menegaskan bahwa kewajiban pemerintah untuk menyediakan akses seluasluasnya bagi seluruh masyarakat untuk mendapatkan pendidikan. Pemerintah mendapat amanat untuk membangun sistem pendidikan nasional yang menjamin pemerataan kesempatan memperoleh pendidikan serta peningkatan mutu, relevansi, dan efisiensi manajemen pendidikan untuk menghadapi tantangan perubahan kehidupan lokal, nasional, dan global (Depdiknas, 2006).

Salah satu amanat Undang-Undang Dasar Negara Republik Indonesia Tahun 1945 tersebut kemudian diatur lebih lanjut dalam Undang-Undang Nomor 20 Tahun 2003 tentang Sistem Pendidikan Nasional, yang memiliki visi terwujudnya sistem pendidikan sebagai pranata sosial yang kuat dan berwibawa untuk memberdayakan semua warga Negara Indonesia berkembang menjadi manusia yang berkualitas sehingga mampu dan proaktif menjawab tantangan zaman yang selalu berubah (Depdiknas, 2003).

Sumber daya manusia yang unggul merupakan persyaratan utama bagi terwujudnya bangsa dan negara yang maju dimana pendidikan merupakan modal dasar untuk menciptakan SDM yang unggul. Khususnya pada lembaga pendidikan sekolah. Demi pencapaian visi dan misi memerlukan tenaga profesional, tata kerja organisasi dan sumber-sumber yang mendukung baik finansial maupun non finansial.

Khususnya guru sebagai tenaga pendidik di sekolah. Kemampuan dan keberhasilan guru dalam melaksanakan tugas-tugas pembelajaran di sekolah dan bertanggung jawab atas peserta didik di bawah bimbingannya dengan meningkatkan prestasi belajar peserta didik disebut dengan kinerja guru. Sebagaimana disampaikan Glasman, kinerja yang baik terlihat dari hasil yang diperoleh dalam penilaian prestasi peserta didik, artinya semakin baik kinerja guru maka prestasi peserta didik akan semakin baik pula (Supardi, 2016).

Dibalik itu, guru memiliki banyak peran yang harus dilaksanakan (Hadiyanto, 2016; Jawab Dra Kristinawati Susatio et al., 2009; Ulfah, Irtawaty, ., Abrar, \& Sorongan, 2017) dan guru 
dituntut memiliki kinerja yang baik. Kinerja guru ditunjukkan oleh hasil kerja sebagaimana disampaikan oleh Lembaga Administrasi Negara (LAN), kinerja merupakan gambaran tentang tingkat pencapaian pelaksanaan suatu kegiatan dalam mewujudkan sasaran (Supardi, 2014). Maka, melalui kinerja guru dapat dilihat sejauh mana ketercapaian tujuan dari pembelajaran yang dilaksanakan. Hal ini menujukkan pentingnya kinerja guru sebagai tolak ukur dalam pencapaian sasaran dalam pembelajaran. Untuk itu sangatlah penting meningkatkan kinerja guru sebagai salah satu upaya meningkatkan kualitas pendidikan.

Berdasarkan pengamatan dan wawancara penulis pada saat grand tour dari tanggal 11 Februari sampai dengan 1 Maret 2019 sebanyak tiga kali di tiap sekolah pada waktu yang berbeda di SD Negeri Kecamatan Payakumbuh Barat Kota Payakumbuh ditemukan beberapa fenomena yang berkaitan dengan permasalahan kinerja guru diantaranya: Pertama, masih ada guru yang enggan mempersiapkan kebutuhan mengajar dan rencana pembelajaran untuk setiap pertemuan. Kedua, masih ada guru yang tidak langsung masuk ke kelas saat bel setelah istirahat berbunyi. Ketiga, masih ada guru yang meninggalkan kelas saat jam pembelajaran berlangsung. Keempat, masih ada guru yang mendominasi kelas dalam proses pembelajaran. Kelima, masih ada guru yang belum menggunakan media pembelajaran yang bervariatif. Keenam, masih ada guru yang belum paham cara mengolah nilai peserta didik menggunakan kurikulum baru.

Sehubungan dengan fenomena yang terjadi di lapangan maka terkait kinerja guru di SMP Negeri Kota Bukittinggi, kepala sekolah harus memperhatikan faktor-faktor yang mempengaruhi kinerja guru.

Salah satu faktor yang mempengaruhi kinerja guru adalah ikim sekolah dalam suatu lembaga atau organisasi. Iklim sekolah atau suasana lingkungan kerja di sekolah adalah segala sesuatu yang di alamioleh guru dan warga sekolah ketika berinteraksi di dalam lingkungan sekolah. Iklim sekolah yang kondusif mempengaruhi kinerja anggota organisasi sekolah. Dengan kata lain, maju atau mundurnya sekolah bergantung pada kemampuan sekolah tersebut menciptakan lingkungan dan kesediaan lingkungan untuk menerima keberadaanya.

Iklim sekolah terjadi karena adanya interaksi antara struktur organisasi yang terbuka, standar kinerja yang dinamis, rasa tanggungjawab guru, keikutsertaan guru dalam organisasi, pengakuan atas hasil pekerjaan, gaya manajemen yang mendukung dan komitmen dalam mengemban tugas (Kasim, Ismail, Mohammad, \& Ibrahim, 2017; Rahawarin \& Arikunto, 2015).

Hasil penelitian yang telah dilakukan menunjukkan bahwa iklim sekolah sekolah berpengaruh positif terhadap kinerja guru di SD Negeri Kecamatan Danau Kembar Kabupaten Solok dengan koefisien regresi 0,623 (Sari, 2018). Iklim sekolah yang kondusif baik fisik maupun non fisik merupakan landasan bagi penyelenggaraan pembelajaran yang efektif dan produktif. Oleh karena itu kepala sekolah sebagai manajer sekolah perlu menciptakan iklim yang kondusif untuk menumbuhkembangkan semangat dan merangsang motivasi belajar peserta didik. 
Berdasarkan uraian tersebut maka masalah faktor-faktor yang mempengaruhi kinerja guru perlu dibuktikan dengan mengadakan penelitian. Oleh karena itu, penulis membuat judul penelitian "Kontribusi Iklim Sekolah dan Kepemimpinan Kepala Sekolahterhadap Kinerja Guru SD Negeri 02 Payakumbuh“"

\section{METODE PENELITIAN}

Penelitian ini menggunakan pendekatan kuantitatif yaitu pendekatan yang menggunakan angka-angka yang diolah melalui analisis statistik non parametrik dalam menganalisis hasil penelitian korelasional. Penelitian ini termasuk dalam jenis penelitian korelasional. Menurut Creswell (2008), penelitian korelasional adalah penelitian yang memberikan kesempatan untuk memprediksi skor tertentu karena adanya skor yang lain dan menerangkan antar variabel. Penelitian ini tergolong kategori korelasional karena mencari ada tidaknya hubungan antara satu variabel dengan variabel yang lain.

Populasi adalah wilayah generalisasi yang terdiri dari atas objek atau subjek yang mempunyai kualitas dan karakteristik tertentu yang di tetapkan oleh peneliti untuk di pelajari dan kemudian ditarik kesimpulannya (Sugiyono, 2014). Pendapat lain menyatakan bahwa populasi adalah keseluruhan dari karakteristik atau unit dari pengukuran yang menjadi objek penelitian (Riduwan, 2002). Jadi dapat di simpulkan bahwa populasi adalah keseluruhan dari subjek penelitian baik berupa barang, benda, tempat atau keadaan waktu. Populasi adalah seluruh guru SD Negeri di Kecamatan Payakumbuh Barat Kota
Payakumbuh yang berjumlah 229 dari 23 sekolah.

\section{HASIL DAN PEMBAHASAN}

Penelitian dilakukan pada tanggal 12 Juli 2019. Penilitian dilakukan pada guru SD di kota Payakumbuh. Berikut adalah data populasi guru SDN di Kota Payakumbuh.

Penyusunan angket dilakukan dengan langkah-langkah sebagai berikut:

1. Menjabarkan variabel menjadi indikator.

2. Menyusun kisi-kisi angket.

3. Mengkonsultasikan angket tersebut dengan pembimbing.

4. Melakukan uji coba angket kepada 20 orang guru SD Negeri di Kecamatan Payakumbuh Barat Kota Payakumbuh selain sampel.

5. Menganalisis hasil uji coba angket untuk mengetahui validitas dan reliabilitas angket

Pengolahan data perhitungan validitas ini menggunakan bantuan program SPSS (Statistic Package and Social Science) 20.00 For Windows (Santoso, 2012). Untuk menentukan butir yang valid dengan cara membandingkan nilai Corrected Item Total Correlation masing-masing butir dengan nilai $r_{\text {tabel }}$ dengan $\mathrm{N}=20$. Apabila nilai Corrected Item Total Correlation $>r_{\text {tabel }}$ maka item dinyatakan "valid".

$$
\text { Pengolahan data perhitungan }
$$
reabilitas ini menggunakan bantuan program SPSS (Statistic Package and Social Science) 20.0 For Windows. Untuk menentukan reliabelitas angket dilakukan dengan cara membandingkan nilai Alpha Cronbach's dengan nilai rho dengan $\mathrm{N}=20$. Apabila nilai 
Alpha Cronbach's $>$ rho Sperman maka angket dinyatakan "reliabel".

Dalam penelitian ini, penulis melakukan pengumpulan data dengan cara penyebaran angket kepada guru SD Negeri di Kecamatan Payakumbuh Barat Kota Payakumbuh yang menjadi sampel dalam penelitian ini. Angket disebarkan dengan cara menemui responden secara langsung dengan menyerahkan instrumen dan mengumpulkan kembali setelah diisi.

Untuk dapat melihat pengaruh kepemimpinan dan supervisi akademik kepala sekolah terhadap kinerja guru SD Negeri di Kecamatan Payakumbuh Barat Kota Payakumbuh maka perlu dilakukan analisis. Data yang terkumpul selanjutnya diverifikasi dan diolah sesuai dengan hasil verifikasi.Analisis data menggunakan teknik regresi dan korelasi sederhana. Analisis data dilakukan dengan menggunakan bantuan komputer SPSS versi 20.0 berikut akan diuraikan langkah-langkah analisis tersebut.

Sebelum dilakukan analisis data secara statistik dengan teknik korelasi dan regresi terlebih dahulu diperiksa persyaratanpersyaratan yang harus dipenuhi yang meliputi:

a. Uji normalitas data dilakukan dengan menggunakan tekhnik Kolmogorof Smirnov (Uji K-S). Pengujian normalitas diperlukan untuk mengetahui apakah data berasal dari populasi yang berdistribusi normal.

b. Uji homogenitas populasi dilakukan dengan menggunakan rumus Chi Square, untuk melihat apakah data membentuk garis yang atau tidak. c. Uji linearitas dilakukan untuk mengetahui bentuk garis hubungan antar variabel bebas dengan variabel terikat. Pemeriksaan dilakukan dengan $U j i$ Levene.

d. Uji indepensi Pemerikasaan independen dimaksudkan untuk melihat variabel bebas mempunyai hubungan yang siknifikan atau tidak. Teknik yang digunakan adalah korelasi product moment.

Pengujian hipotesis dilakukan dengan melakukan korelasi dan regresi dengan bantuan program SPSS sebagai berikut :

a. Untuk menguji hipotesis 1 dan 2 digunakan teknik korelasi dan regresi sederhana.

b. Untuk menguji hipotesis 3 digunakan teknik korelasi dan regresi ganda.

c. Untuk mengetahui salah satu variabel (X1 dan X2 ) dengan variabel (Y) dengan mengontrol salah satu variabel bebas dan untuk mengetahui korelasi efektif secara murni dan sebuah variabel bebas maka digunakan teknik korelasi parsial.

\section{Tabel 1. Daftar Guru SD berdasarkan} pendidikan dan golongan

\begin{tabular}{|c|c|c|c|c|c|c|}
\hline \multirow{3}{*}{ No } & \multirow{3}{*}{$\begin{array}{c}\text { Nama } \\
\text { Sekolah }\end{array}$} & \multicolumn{4}{|c|}{ Pendidikan/Golongan } & \multirow{3}{*}{$\begin{array}{l}\text { Jumlah } \\
\text { Populasi }\end{array}$} \\
\hline & & \multicolumn{2}{|c|}{ S1 } & \multicolumn{2}{|c|}{ S2 } & \\
\hline & & $\leq$ III & IV & $\leq$ III & IV & \\
\hline 1. & $\begin{array}{l}\text { SD Negeri } 02 \\
\text { Payakumbuh }\end{array}$ & 10 & 12 & - & 2 & A. 24 \\
\hline 2. & $\begin{array}{l}\text { SD Negeri } 07 \\
\text { Payakumbuh }\end{array}$ & 4 & 7 & - & 1 & B. 12 \\
\hline 3. & $\begin{array}{l}\text { SD Negeri } 09 \\
\text { Payakumbuh }\end{array}$ & 5 & 6 & 1 & - & C. 12 \\
\hline 4. & $\begin{array}{l}\text { SD Negeri } 13 \\
\text { Payakumbuh }\end{array}$ & 3 & 4 & - & - & D. 7 \\
\hline 5. & $\begin{array}{l}\text { SD Negeri } 14 \\
\text { Payakumbuh }\end{array}$ & 3 & 3 & - & - & E. 6 \\
\hline 6. & $\begin{array}{l}\text { SD Negeri } 18 \\
\text { Payakumbuh }\end{array}$ & 3 & 5 & - & - & F. 8 \\
\hline
\end{tabular}


Kontribusi iklim sekolah dan kepemimpinan kepala sekolah terhadap kinerja guru sekolah dasarIdeswal, Yahya, hanif Alkadri, Ahmad Zikri

\begin{tabular}{|c|c|c|c|c|c|c|}
\hline 7. & $\begin{array}{l}\text { SD Negeri } 26 \\
\text { Payakumbuh }\end{array}$ & 7 & 10 & 1 & 1 & G. 19 \\
\hline 8. & $\begin{array}{l}\text { SD Negeri } 28 \\
\text { Payakumbuh }\end{array}$ & 5 & 9 & - & 1 & H. 15 \\
\hline 9. & $\begin{array}{l}\text { SD Negeri } 29 \\
\text { Payakumbuh }\end{array}$ & 3 & 4 & - & - & I. 7 \\
\hline 10. & $\begin{array}{l}\text { SD Negeri } 30 \\
\text { Payakumbuh }\end{array}$ & 2 & 5 & 1 & - & $J .8$ \\
\hline 11. & $\begin{array}{l}\text { SD Negeri } 35 \\
\text { Payakumbuh }\end{array}$ & 3 & 4 & - & 1 & K. 8 \\
\hline 12. & $\begin{array}{l}\text { SD Negeri } 39 \\
\text { Payakumbuh }\end{array}$ & 4 & 4 & - & - & L. 8 \\
\hline 13. & $\begin{array}{l}\text { SD Negeri } 40 \\
\text { Payakumbuh }\end{array}$ & 2 & 5 & - & - & M. 7 \\
\hline 14. & $\begin{array}{l}\text { SD Negeri } 44 \\
\text { Payakumbuh }\end{array}$ & 3 & 5 & - & - & $N .8$ \\
\hline 15. & $\begin{array}{l}\text { SD Negeri } 45 \\
\text { Payakumbuh }\end{array}$ & 3 & 4 & - & 1 & O. 8 \\
\hline 16. & $\begin{array}{l}\text { SD Negeri } 46 \\
\text { Payakumbuh }\end{array}$ & 5 & 6 & - & 2 & P. 13 \\
\hline 17. & $\begin{array}{l}\text { SD Negeri } 49 \\
\text { Payakumbuh }\end{array}$ & 6 & 6 & 1 & 1 & Q. 14 \\
\hline 18. & $\begin{array}{l}\text { SD Negeri } 54 \\
\text { Payakumbuh }\end{array}$ & 3 & 4 & - & - & R. 7 \\
\hline 19. & $\begin{array}{l}\text { SD Negeri } 55 \\
\text { Payakumbuh }\end{array}$ & 4 & 4 & - & - & S. 8 \\
\hline 20. & $\begin{array}{l}\text { SD Negeri } 58 \\
\text { Payakumbuh }\end{array}$ & 3 & 5 & - & - & T. 8 \\
\hline 21. & $\begin{array}{l}\text { SD Negeri } 59 \\
\text { Payakumbuh }\end{array}$ & 3 & 4 & 1 & - & $U .8$ \\
\hline & Total & 89 & $\begin{array}{c}12 \\
4\end{array}$ & 5 & 11 & 229 \\
\hline
\end{tabular}

Hasil penelitian menunjukkan terdapat kontribusi antara iklim sekolah dengan kinerja guru di SDN di kota Payakumbuh melalui persamaan garis regresi $=140,03 \mathrm{X} 1$, dengan $\mathrm{F}=$ 4,12 dan sinifikansi $0,028<0,05$. Terdapat korelasi yang signifikan antara kontribusi iklim sekolah dengan kinerja guru di SDN kota Payakumbuh dengan $r$ hitung $=0,28$, dengan koefesien determinasi sebesar 0,090. Dengan demikian kontribusi kepemimpinan kepala sekolah terhadap prestasi guru sebesar 9,0\% .

Kedua, terdapat kontribusi antara kepemimpinan kepala sekolah dengan kinerja guru SD di kota Payakumbuh melalui persamaan garis regresi $=167,282-0,391 \mathrm{X} 2$, dengan $\mathrm{F}=4,698$ dan sinifikansi $0,054<0,05$. Dalam penelitian ini ditemukan korelasi yang signifikan antara kontribusi kepemimpinan kepala sekolah dengan kinerja guru SDN di kota Payakumbuh dengan $r$ hitung $=0,296$. Dengan koefesien determinasi sebesar 0,086. Dengan demikian kepemimpinan kepala sekolah terhadap prestasi guru sebesar $8,6 \%$. Sumbangan efektif (SE) kontribusi kepemimpinan kepala sekolah terhadap kinerja guru sebesar $7,42 \%$.

\section{SIMPULAN}

Berdasarkan hasil analisis dan pembahasan, maka simpulan dapat diambil antara lain sebagai berikut:

1. Terdapat kontribusi antara iklim sekolah dengan kinerja guru di SDN di kota Payakumbuh sebesar 9,0\%.

2. Terdapat kontribusi antara kepemimpinan kepala sekolah dengan kinerja guru SDN di kota Payakumbuh sebesar 8,6\%.

\section{DAFTAR PUSTAKA}

Depdiknas. (2003). Undang-Undang Ri No 20 Tahun 2003. Undang-Undang Republik Indonesia Nomor 20 Tahun 2003 Tentang Sistem Pendidikan Nasional Dengan Rahmat Tuhan Yang Maha Esa Presiden Republik Indonesia.

Depdiknas. (2006). Panduan Penyusunan Kurikulum Tingkat Satuan Pendidikan. Jakarta: Bnsp Depdiknas.

Fadhli, M. (2017). Manajemen Peningkatan Mutu Pendidikan. Tadbir : Jurnal Studi Manajemen Pendidikan.

Https://Doi.Org/10.29240/Jsmp.V1i2.295

Hadiyanto. (2016). Membantu Guru Meningkatkan Pendidikan Karakter Menuju Bangsa Yang Beradap Melalui Perbaikana Iklim Kelas. Konvensi Nasional Pendidikan Indonesia (Konaspi) Vii.

Kristinawati Susatio, Hadiyanto Budisetio, Ms., \& Mulyani. (2009). Motivasi Kerja Guru Dalam Mengembangkan Kurikulum Sekolah. Jurnal Pendidikan Penabur.

Kasim, M. A. B. M., Ismail, S. N., Mohammad, S., \& Ibrahim, H. (2017). Iklim Sekolah Dan 
466 Kontribusi iklim sekolah dan kepemimpinan kepala sekolah terhadap kinerja guru sekolah dasarIdeswal, Yahya, hanif Alkadri, Ahmad Zikri

Komitmen Guru Di Sekolah Agama Bantuan Kerajaan (Sabk) Negeri Kelantan. Proceedings Of The Icecrs. Https://Doi.Org/10.21070/Picecrs.V1i1.543

Muhson, A. (2010). Pengembangan Media Pembelajaran Berbasis Teknologi Informasi. Jurnal Pendidikan Akuntansi Indonesia. Https://Doi.Org/10.21831/Jpai.V8i2.949

Permendikbud. (2013). Peraturan Pendidikan Dan Kebudayaan Republik Indonesia. Peraturan Menteri Pendidikan Dan Kebedayaan.

Rahawarin, C., \& Arikunto, S. (2015). Pengaruh Komunikasi, Iklim Organisasi Dan Gaya Kepemimpinan Transformasional Kepala Sekolah Terhadap Kinerja Guru Sma. Jurnal Akuntabilitas Manajemen Pendidikan. Https://Doi.Org/10.21831/Amp.V3i2.6334

Rakhmawati, S., Muspiroh, N., Azmi, N., Pd, S. I., Tadris, J., Biologi, I., ... Cirebon, S. (2016). Analisis Pelaksanaan Kurikulum 2013 Ditinjau Dari Standar Proses Dalam Pembelajaran Biologi Kelas X Di Sma Negeri 1 Krangkeng. Scientiae Educatia: Jurnal Sains Dan Pendidikan Sains.

Republik Indonesia. (2005). Undang-Undang Nomor 14 Tahun 2005 Tentang Guru Dan Dosen. Sekretariat Negara.

Sugiyono. (2014). Populasi Dan Sampel. Metode Penelitian Kuantitatif, Kualitatif Dan R\&D.

Supardi. (2014). Kontribusi Supervisi Kepala Madrasah, Iklim Kerja, Dan Pemahaman Kurikulum Terhadap Kinerja Guru Madrasah Aliyah. Jurnal Pendidikan Dan Kebudayaan. Https://Doi.Org/10.24832/Jpnk.V20i1.133

Supardi, E. (2016). Pengembangan Karir Kontribusinya Terhadap Kinerja Pegawai. Jurnal Geografi Gea. Https://Doi.Org/10.17509/Gea.V9i1.1680

Suwardana, H. (2018). Revolusi Industri 4. 0 Berbasis Revolusi Mental. Jati Unik : Jurnal Ilmiah Teknik Dan Manajemen Industri. Https://Doi.Org/10.30737/Jatiunik.V1i2.117

Ulfah, M., Irtawaty, A. S., . H., Abrar, A., \& Sorongan, E. (2017). Peningkatan Kompetensi Guru Dengan Pemanfaatan Ict Melalui Aplikasi Proteus Di Smk Setia Budi Balikpapan. Adimas: Jurnal Pengabdian Kepada Masyarakat. Https://Doi.Org/10.24269/Adi.V1i2.600 